\title{
Comparison of four COVID-19 screening strategies to facilitate early case identification within the homeless shelter population: A structured summary of a study protocol for a randomised controlled trial
}

Timothy O'Shea ${ }^{1 *}$, Lawrence Mbuagbaw², Vaibhav Mokashi ${ }^{3} \mathbb{D}$, David Bulir ${ }^{4}$, Jodi Gilchrist ${ }^{5}$, Nicole Smieja ${ }^{5}$, Sylvia Chong ${ }^{5}$, Sarah Marttala ${ }^{5}$, Valentina Vera ${ }^{5}$, Anna Cvetkovic $^{3}$ and Marek Smieja ${ }^{4}$

\begin{abstract}
Objectives: 1. To compare the effectiveness of four different surveillance strategies in detecting COVID-19 within the homeless shelter population.

2. To assess the participant adherence over time for each surveillance method.

Trial Design: This is a prospective cluster-randomized study to compare the effectiveness of four different surveillance regimens across eight homeless shelters in the city of Hamilton.

Participants: Participants will include both residents of, and the staff working within, the homeless shelters. All participants aged 18 or older who consent to the study and are able to collect a swab sample (where relevant) are eligible for the study. The study will take place across eight homeless shelters (four men-only and four womenonly) in the City of Hamilton in Ontario, Canada.

Intervention and Comparator Groups: The comparator group will receive active daily surveillance of symptoms and testing will only be completed in symptomatic participants (i.e. those who fail screening or who seek care for potential COVID-19 related symptoms).

The three intervention arms will all receive active daily surveillance of symptoms and testing of symptomatic participants (as in the comparator group) in addition to one of the following:

1. Once weekly self-collected oral swabs (OS) regardless of symptoms using written and visual instructions.

2. Once weekly self-collected oral-nares swab (O-NS) regardless of symptoms using written and visual instructions.

(Continued on next page)
\end{abstract}

\footnotetext{
* Correspondence: osheat@mcmaster.ca

'Department of Medicine (Infectious Diseases), Hamilton Shelter Health

Network, Juravinski Hospital \& Cancer Centre, McMaster University, A3-66,

711 Concession Street, Hamilton, ON L8V 1C3, Canada

Full list of author information is available at the end of the article
}

(c) The Author(s). 2020 Open Access This article is licensed under a Creative Commons Attribution 4.0 International License, which permits use, sharing, adaptation, distribution and reproduction in any medium or format, as long as you give appropriate credit to the original author(s) and the source, provide a link to the Creative Commons licence, and indicate if changes were made. The images or other third party material in this article are included in the article's Creative Commons licence, unless indicated otherwise in a credit line to the material. If material is not included in the article's Creative Commons licence and your intended use is not permitted by statutory regulation or exceeds the permitted use, you will need to obtain permission directly from the copyright holder. To view a copy of this licence, visit http://creativecommons.org/licenses/by/4.0/ The Creative Commons Public Domain Dedication waiver (http://creativecommons.org/publicdomain/zero/1.0/) applies to the data made available in this article, unless otherwise stated in a credit line to the data. 
(Continued from previous page)

3. Once weekly nurse collected nasopharyngeal swab (NPS) regardless of symptoms.

Participants will follow verbal and written instructions for the collection of OS and O-NS specimens. For OS collection, participants are instructed to first moisten the swab on their tongue, insert the swab between the cheek and the lower gums and rotate the swab three times. This is repeated on the other side. For O-NS collection, after oral collection, the swab is inserted comfortably (about $2-3 \mathrm{~cm}$ ) into one nostril, parallel to the floor and turned three times, then repeated in the other nostril. NPS specimens were collected by the nurse following standard of care procedure.

All swabs were placed into a viral inactivation medium and transported to the laboratory for COVID-19 testing. Briefly, total nucleic acid was extracted from specimens and then amplified by RT-PCR for the UTR and Envelope genes of SARS-CoV-2 and the human RNase P gene, which is used as a sample adequacy marker.

Main Outcomes: 1. Primary outcome: COVID-19 detection rate, i.e. the number of new positive cases over the study period of 8 weeks in each arm of the study.

2. Secondary outcomes: Qualitative assessment of study enrollment over 8 weeks. Percentage of participants who performed $50 \%$ or more of the weekly swabs in the intervention arms in the 8 week study period.

Randomization: We will use a computer-generated random assignment list to randomize the shelters to one of four interventions. Shelters were stratified by gender, and the simple randomization scheme was applied within each stratum. The randomization scheme was created using WinPEPI.

Blinding: This is an open-label study in which neither participants nor assessors are blinded.

Numbers to be randomized (sample size): Since we are including our total sample frame, a sample size estimation at the cluster level is not required. However, if we succeed to enroll 50 participants per shelter from 8 shelters $(n=400)$, and the detection rate is 3 times higher in the intervention groups $(0.15)$ than in the comparator groups (0.05), we will have 90\% power to detect a statistically significant and clinically important difference at a type I error rate of alpha=0.05 (one tailed), assuming an intraclass correlation of $\sim 0.008$. These computations were done using WinPEPI, and informed by conservative estimates from other studies on respiratory illness in the homeless (see Full protocol).

Trial Status: The protocol version number is 3.0. Recruitment began on April 17, 2020 and is ongoing. Due to low numbers of COVID cases in the community and shelter system during the initial study period, the trial was extended. The estimated date for the end of the extended recruitment period is Feb 1, 2021.

Trial Registration: The trial was registered with ClinicalTrials.gov on June 18, 2020 with the identifier NCT04438070.

Full protocol: The full protocol is attached as an additional file, accessible from the Trials website (Additional file 1). In the interest in expediting dissemination of this material, the familiar formatting has been eliminated; this Letter serves as a summary of the key elements of the full protocol.

Keywords: COVID-19, Randomized trial, protocol, screening, homeless, shelter, swabs, prevention

\section{Supplementary Information}

Supplementary information accompanies this paper at https://doi.org/10. 1186/s13063-020-04890-2.

Additional file 1. Full study protocol

\section{Acknowledgements}

Not applicable.

\section{Authors' contributions}

All authors contributed equally to this study and submission. The author(s) read and approved the final manuscript.

\section{Funding}

Funding from the study was provided by the Hamilton Academic Hospital Organization (HAHSO) and The Research Institute of St. Joe's Hamilton.

\section{Availability of data and materials \\ Not applicable}

\section{Ethics approval and consent to participate}

The trial was approved by the Hamilton Integrated Research Ethics Board on April 14, 2020 (ID\# 10864). Verbal consent was obtained and recorded for all participants in the study.

\section{Consent for publication}

Not applicable.

\section{Competing interests}

The authors declare that they have no competing interests.

\section{Author details}

${ }^{1}$ Department of Medicine (Infectious Diseases), Hamilton Shelter Health Network, Juravinski Hospital \& Cancer Centre, McMaster University, A3-66, 711 Concession Street, Hamilton, ON L8V 1C3, Canada. ${ }^{2}$ Department of 
Health Research, Faculty of Health Sciences, Methods, Evidence and Impact, McMaster University, Hamilton, Canada. ${ }^{3}$ Department of Medicine (Infectious Diseases), McMaster University, Hamilton, Canada. ${ }^{4}$ Department of Medicine, Pathology and Molecular Medicine, Research St. Joseph's - Hamilton, McMaster University, Hamilton, ON, Canada. ${ }^{5}$ Research St. Joseph's Hamilton, Hamilton, ON, Canada.

Received: 9 November 2020 Accepted: 11 November 2020 Published online: 23 November 2020

\section{Publisher's Note}

Springer Nature remains neutral with regard to jurisdictional claims in published maps and institutional affiliations.

Ready to submit your research? Choose BMC and benefit from:

- fast, convenient online submission

- thorough peer review by experienced researchers in your field

- rapid publication on acceptance

- support for research data, including large and complex data types

- gold Open Access which fosters wider collaboration and increased citations

- maximum visibility for your research: over $100 \mathrm{M}$ website views per year

At $\mathrm{BMC}$, research is always in progress.

Learn more biomedcentral.com/submissions 